\title{
Methylprednisolone inhibits the proliferation and affects the differentiation of rat spinal cord-derived neural progenitor cells cultured in low oxygen conditions by inhibiting HIF-1 $\alpha$ and Hes1 in vitro
}

\author{
WENHAO WANG ${ }^{1 *}$, PENG WANG ${ }^{1 *}$, SHIYUAN LI $^{2}$, JIEWEN YANG $^{3}$, XINJUN LIANG ${ }^{1}$, \\ YONG TANG $^{1}$, YUXI LI ${ }^{1}$, RUI YANG ${ }^{1}$, YANFENG WU ${ }^{3}$ and HUIYONG SHEN ${ }^{1}$ \\ ${ }^{1}$ Department of Orthopedics, Sun Yat-sen Memorial Hospital, Sun Yat-sen University, Guangzhou, \\ Guangdong 510120; ${ }^{2}$ Foshan Hospital of Sun Yat-sen University, Foshan, Guangdong 528000; \\ ${ }^{3}$ Biotherapy Center, Sun Yat-sen Memorial Hospital, Guangzhou, Guangdong 510120, P.R. China
}

Received February 9, 2014; Accepted June 5, 2014

DOI: $10.3892 / \mathrm{ijmm} .2014 .1835$

\begin{abstract}
Although there is much controversy over the use of methylprednisolone (MP), it is one of the main drugs used in the treatment of acute spinal cord injury (SCI). The induction of the proliferation and differentiation of endogenous neural progenitor cells (NPCs) is considered a promising mode of treatment for SCI. However, the effects of MP on spinal cord-derived endogenous NPCs in a low oxygen enviroment remain to be delineated. Thus, the aim of this study was to investigate the potential effects of MP on NPCs cultured under low oxygen conditions in vitro and to elucidate the molecular mechanisms involved. Fetal rat spinal cord-derived NPCs were harvested and divided into 4 groups: 2 groups of cells cultured under normal oxygen conditions and treated with or without MP, and 2 groups incubated in $3 \% \mathrm{O}_{2}$ (low oxygen) treated in a similar manner. We found that MP induced suppressive effects on NPC proliferation even under low oxygen conditions $\left(3 \% \mathrm{O}_{2}\right)$. The proportion of nestinpositive NPCs decreased from $51.8 \pm 2.46 \%$ to $36.17 \pm 3.55 \%$ following the addition of MP and decreased more significantly to $27.20 \pm 2.68 \%$ in the cells cultured in $3 \% \mathrm{O}_{2}$. In addition, a smaller number of glial fibrillary acidic protein (GFAP)-positive cells and a greater number of microtubule-associated protein 2 (MAP2)-positive cells was observed following the addition of MP under both normal (normoxic) and low oxygen (hypoxic) conditions. In response to MP treatment, hypoxia-inducible factor- $1 \alpha(\mathrm{HIF}-1 \alpha)$ and the Notch signaling pathway down-
\end{abstract}

Correspondence to: Dr Huiyong Shen, Department of Orthopedics, Sun Yat-sen Memorial Hospital, Sun Yat-sen University Guangzhou, 107 West Yanjiang Road, Guangzhou, Guangdong 510120, P.R. China E-mail: shenhuiyong@aliyun.com

${ }^{*}$ Contributed equally

Key words: methylprednisolone, neural progenitor cell, low oxygen, hypoxia induced factor- $1 \alpha$, Hes 1 stream protein, Hes1, but not the upstream Notch-1 intracelluar domain (NICD), were inhibited. After blocking NICD with a $\gamma$-secretase inhibitor (DAPT) MP still inhibited the expression of Hes1. Our results provide insight into the molecular mechanisms responsible for the MP-induced inhibition of proliferation and its effects on differentiation and suggest that HIF-1 $\alpha$ and Hes1 play an important role in this effect.

\section{Introduction}

Although there is much controversy over the use of methylprednisolone (MP), it is currently one of the main drugs used in the treatment of acute spinal cord injury (SCI). Following traumatic spinal cord injury, an ischemic and low oxygen enviroment exists in both primary and secondary lesions $(1,2)$. It is well known under low oxygen conditions, hypoxia-inducible factor-1 $\alpha(\mathrm{HIF}-1 \alpha)$ will not undergo proteosomal degradation and plays a key role in a series of reactions associated with protoming the survival of cells and helping them adapt to low oxygen (3). A previous study demonstrated that between conditions of anoxia to $20 \% \mathrm{O}_{2}$, the highest proliferation of mouse neural stem cells was observed at $2-3 \%$ oxygen (4). Certain studies have shown that hypoxic conditions increase the formation and proliferation of neural progenitor cells (NPCs) and the proportion of neurons $(5,6)$. The study by Schröter et al (7), as well as our previous study, demonstrated that corticosteroids inhibit the proliferation of NPCs in vitro and following SCI (8). However, dexamethasone has been shown to have an inhibitory effect on HIF-1 $\alpha$ in T cells (9). To the best of our knowledge, the effects of MP on HIF-1 $\alpha$ in NPCs have not been reported to date. Certain studies have demonstrated the regulatory function of HIF-1 $\alpha$ on the proliferation and differentiation of several stem cell types through Notch signaling components under low oxygen conditions $(10,11)$. However, inhibiting Notch signaling leads to NPC differentiation, including an increased proportion of neurons in the rat brain (12).

The effects of MP on the proliferation and differentiation of rat spinal cord-derived NPCs, as well as the mechanisms 
involved remain to be elucidated. Thus, in this study, we treated NPCs cultured under both normal oxygen (normoxic) and low oxygen (hypoxic) conditions with or without MP to determine whether any changes occur in HIF-1 $\alpha$ expression and Notch signaling, as well as to elucidate the possible effects of MP on the proliferation and differentiation of NPCs in vitro.

\section{Materials and methods}

Ethics approval. All procedures involving animals were approved by the 'Committee for the Care and Use of Laboratory Animals' of Sun Yat-sen University College of Medicine, Guangzhou, China.

Cell culture and characterization by immunocytochemistry. Spinal cords were isolated from neonatal (1-day-old) Sprague-Dawley rats under a microscope and digested by repeated trituration with fire-polished Pasteur pipettes into single cells, according to a previously described method for spinal cord stem cells $(13,14)$ The cells were incubated and passaged in medium, as described in our previous study (8) The 2nd generation of neurospheres was used in all the experiments. The antibodies used in this study were as follows: primary antibodies to nestin (mouse anti-rat, 1:400; Millipore Corp., Billerica, MA, USA), microtubule-associated protein 2 (MAP2; rabbit anti-rat, 1:100; Sigma-Aldrich, St. Louis, MO, USA) and glial fibrillary acidic protein (GFAP; rabbit anti-rat, 1:500), as well as anti-oligodendrocyte-specific protein antibody (Oligo; rabbit anti-rat; 1:100) (both from Abcam, Cambridge, MA, USA); and the secondary antibodies, FITC goat anti-mouse or Cy3 goat anti-rabbit (1:200; Jackson ImmunoResearch Laboratories, Inc., West Grove, PA, USA). The fluorochrome Hoechst 33342 (Cell Signaling Technology, Danvers, MA, USA) was used to stain the nuclei. Low oxygen conditions were generated by aerating the cell incubator chamber (Galaxy 48R; New Brunswick, Hamburg, Germany) with $\mathrm{CO}_{2}$ and $\mathrm{N}_{2}$. The modulator can adjust the $\mathrm{O}_{2}$ concentration to target the oxygen level to $3 \%, \mathrm{CO}_{2}$ to $5 \%$ and $\mathrm{N}_{2} 92 \%$. Immunocytochemistry was performed as described in our previous study (8). Images were captured using an inverted fluorescence microscope (Carl Zeiss, Inc., Oberkochen, Germany).

Cell quantitative analysis and CCK-8 assay. The 2nd generation of NPCs was split into to 2 main groups (with $20 \% \mathrm{O}_{2}$ for the control, with $3 \% \mathrm{O}_{2}$ for the experimental group). Each group was divided into 3 subgroups, each treated with a different concentration of MP $(0 \mu \mathrm{g} / \mathrm{ml}$ as the control, or 3 and $10 \mu \mathrm{g} / \mathrm{ml}$ ). The cells were plated into 6-well plates (BD Falcon/BD Biosciences, Franklin Lakes, NJ, USA) at a density of $5 \times 10^{4}$ cells $/ \mathrm{ml} \mathrm{(} 3 \mathrm{ml}$ cell suspension per well). Every $24 \mathrm{~h}$ all samples were removed from the cell incubator and digested into a single cell suspension and were randomly and repeatedly counted by 2 individuals using a cell counting chamber for 7 days. A density of $1.5 \times 10^{4}$ cells $/ \mathrm{ml}$ was planted into a 96 -well flat bottom plate $(0.2 \mathrm{ml}$ per well). Each sample was divided into 3 wells for repetition. Three neonatal rats were used as biological replicates. In total, 10 plates (half with $20 \% \mathrm{O}_{2}$, and the other with $3 \% \mathrm{O}_{2}$ ) were planted. Every 24 h CCK-8 solution (Dojindo Laboratories, Kumamoto, Japan) was added to 2 plates (one in $20 \% \mathrm{O}_{2}$, and the other in
$3 \% \mathrm{O}_{2}$ ), followed by incubation at $37^{\circ} \mathrm{C}$ for $4 \mathrm{~h}$ and subsequent testing using a microplate reader (Varioskan; Thermo Fisher Scientific, Waltham, MA, USA). Each well was detected at an excitation light length of 450 and $630 \mathrm{~nm}$. The final optical density (OD) value was made firstly by all values at $450 \mathrm{~nm}$ OD value, substracting the $630 \mathrm{~nm}$ OD value, then substracting the OD value of the blank well (culture medium only) .

Quantitative reverse transcription PCR. The NPCs were incubated for $24 \mathrm{~h}$. The 2 main groups ( 3 or $20 \% \mathrm{O}_{2}$ ) were divided into 2 subgroups, each treated with a different concentration of MP ( 0 or $10 \mu \mathrm{g} / \mathrm{ml})$. Total RNA was extracted using TRIzol reagent (Invitrogen, Carlsbad, CA, USA) according to the manufacturer's instructions and the RNA concentration was determined using a NanoDrop spectrophotometer (from Thermo Fisher Scientific). cDNA was reverse transcribed using PrmieScript RT Master mix (Takara Bio, Dalian, China) with 200 ng RNA per sample. Quantitative PCR (qPCR) was performed on a real-time PCR instrument (light cycler 480; Roche, Mannheim, Germany), using SYBR Premix Ex Taq ${ }^{\mathrm{TM}}$ II (Tli RNaseH Plus; Takara code no. DRR820A). All data were normalized to the housekeeping gene, $\beta$-actin (ACTIN). The primers used in the real-time PCR amplification were as follows: $\beta$-actin forward, 5'-GGAGATTACTGCCCTGGCT CCTA-3' and reverse, 5'-GACTCATCGTACTCCTGCTT GCTG-3; HIF-1 $\alpha$ forward, 5'-CCAGATTCAAGATCAGCC AGCA-3' and reverse, 5'-GCTGTCCACATCAAAGCAGT ACTCA-3'; VEGF forward, 5'-TGGACCCTGGCTTTACT GCTG-3' andreverse,5'-GGCAATAGCTGCGCTGGTAGA-3'; phosphoglycerate kinase (PGK1) forward, 5'-TCCATGGT GGGTGTGAATCTG-3' and reverse, 5'-CAGCTGGATCTTG TCTGCAACTTTA-3'; and Hes1 forward, 5'-CAACACGAC ACCGGACAAAC-3' and reverse, 5'-TTGGAATGCCGGG AGCTATC-3'. All data were normalized to the housekeeping gene, $\beta$-actin (ACTIN).

Western blot analysis of extracts. The cells were placed into 6 -well plates at $3 \mathrm{ml}$ per well (cell density, $50 \times 10^{4}$ cells $/ \mathrm{ml}$ ). The 2 main groups (treated with $10 \mu \mathrm{M}$ DAPT or without DAPT), were divided into 4 subgroups (cultured in $20 \% \mathrm{O}_{2}$ and treated with 0 or $10 \mu \mathrm{g} / \mathrm{ml} \mathrm{MP}$ for $48 \mathrm{~h}$; or cultured in $3 \% \mathrm{O}_{2}$ and treated with 0 or $10 \mu \mathrm{g} / \mathrm{ml} \mathrm{MP}$ for $48 \mathrm{~h})$. Cell lysis buffer was then added (50 mM Tris $\mathrm{pH} 7.4,150 \mathrm{mM} \mathrm{NaCl}, 1 \%$ Triton $\mathrm{X}-100$, $1 \%$ sodium deoxycholate, $0.1 \%$ SDS and $1 \mathrm{mM}$ PMSF) containing protease inhibitor cocktail tablets (Roche). Protein concentrations were measured using the BCA protein assay in a spectrophotometer (Multiskan; Thermo Fisher Scientific) at $562 \mathrm{~nm}$. In each lane, $20 \mu \mathrm{g}$ protein sample was serperated on a $10 \%$ SDS-polyacrylamide gel (SDS-PAGE) then transferred onto a PVDF membrane (Millipore Corp.). The membrane was then incubated with primary antibody with $5 \%$ BSA overnight at $4^{\circ} \mathrm{C}$. The primary antibodies were as follows: anti- $\beta$-actin (1:1,000; Cell Signaling Technology); anti-HIF-1 $\alpha$ (1:500; Novus Biologicals, Ltd., Cambridge, UK); anti-Hes1 (1:1,000; Abcam); anti-Notch 1 intracelluar domain (NICD) (cleaved Notch 1) (1:1,000; Cell Signaling Technology). DAPT (an NICD blocker; Tocris, Ballwin, MO, USA) was diluented into $10 \mu \mathrm{M}$ per well. The blots were incubated for $1 \mathrm{~h}$ with horseradish peroxidase secondary antibodies (Millipore Corp.). Immunoreactive protein bands were detected and visualized 


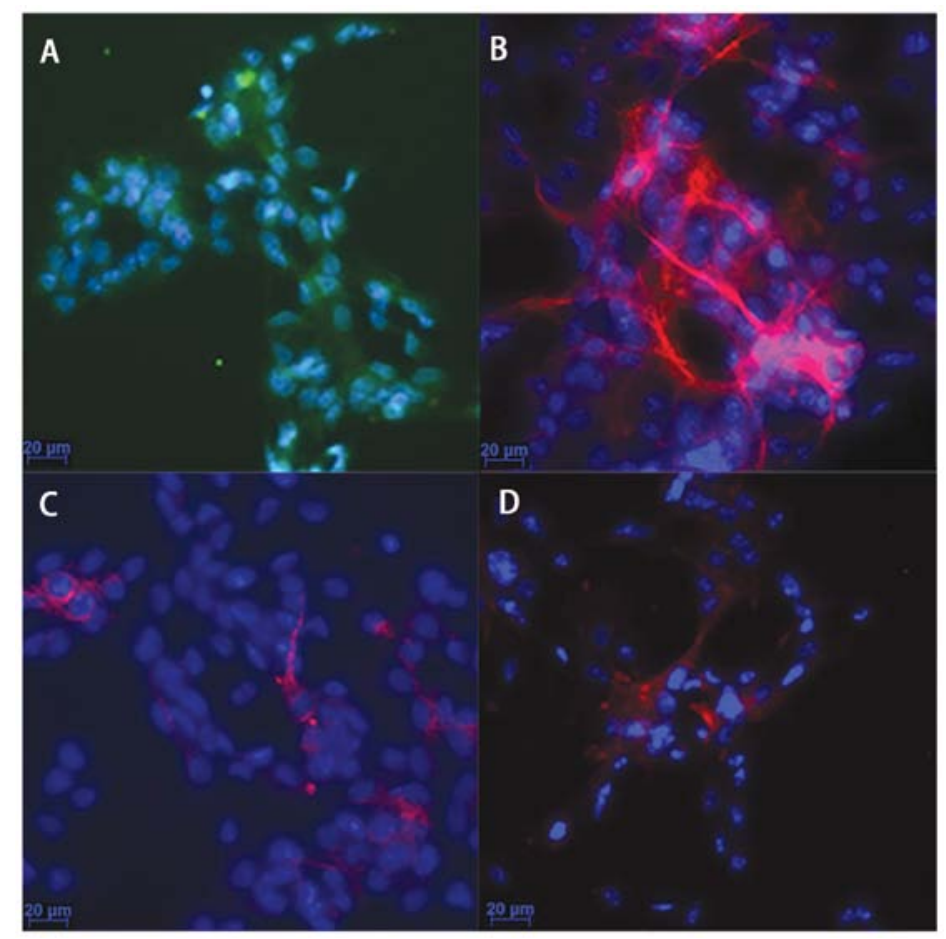

Figure 1. Characterization of neural progenitor cells (NPCs) by immunocytochemistry. All cells were detected after 3 days of growth on adherent substrate with $5 \%$ (v/v) fetal bovine serum (Hoechst-positive nuclei are blue) (magnification, $\mathrm{x} 40$ ). (A) The majority of the NPCs were nestin-positive (green); (B) GFAPpositive (red) astrocytes were abundant; (C) MAP2-positive (red) neurons and (D) Oligo-positive (red) oligodendrocytes were detected only in small quantities . (A-D) Bars, $20 \mu \mathrm{m}$.

in a Gel imaging box (G:BOX Chemi; Sygene Technologies Corp., Palos Heights, IL, USA) with ECL substrate (Pierce Biotechnology, Inc., Rockford, IL, USA).

Fluorescence-activated cell sorting (FACS). Cell grouping and treatment were the same as for western blot analysis. Following 3 days in culture with 5\% fetal bovine serum (FBS), the cells were tenderly blown into single cells in $0.05 \%$ trypsin using a Pasteur pipette and then treated with fixation and permeabilization reagents (Invitrogen). Followng incubation with primary antibody to nestin (1:500; Sigma-Aldrich), GFAP (1:500; Abcam) or MAP2 (1:500; Sigma-Aldrich), the cells were centrifuged and rinsed with PBS twice. FITC (1:1,000; Jackson Immunoresearch Laboratories) was used as the secondary antibody. FACS was performed in a flow cytometer (BD FACSCalibur; BD Biosciences).

Statistical analysis. One-way ANOVA followed by least significant difference (LSD) multiple comparisons t-tests were used to determine statistical significance. $P$ values were derived from at least 3 independent experiments. A value of $\mathrm{P}<0.05$ was considered to indicate a statistically significant difference.

\section{Results}

Cell culture and characterization. As observed under a light microscope, the cells had a round shape, bright plasma and formed neurospheres. Following the addition of 5\% FBS and normal culture for 3 days, different cellular processes were observed. The results from immunocytochemistry (Fig. 1) revealed that the majority of the cultured cells were nestin- positive (Fig. 1A), a marker of NPCs; the GFAP-positive cells were abundant (Fig. 1B), indicating that the majority of the NPCs had differentiated into astrocytes; the neurons (MAP2positive cells; Fig. 1C) and oligodendrocytes (Oligo4-positive cells; Fig. 1D) were a minority. These results demonstrated that the cultured cells were NPCs and were able to differentiate into other types of neural cells.

A low oxygen enviroment promotes NPC proliferation, but MP inhibits NPC proliferation even under low oxygen conditions. Cell quantitative analysis and CCK-8 assay indicated that the NPCs not treated with MP $(0 \mu \mathrm{g} / \mathrm{ml})$ proliferated more rapidly when cultured in $3 \% \mathrm{O}_{2}$ than in $20 \% \mathrm{O}_{2}$ following treatment with MP $(\mathrm{P}<0.05)$ (Fig. 2A and $\mathrm{B})$. The proliferation of the cells cultured in either 20 or $3 \% \mathrm{O}_{2}$ was markedly inhibited following treatment with MP from day 2 of culture $(\mathrm{P}<0.05)$ (Fig. 2A). The increase in the concentration of MP from 3 to $10 \mu \mathrm{g} / \mathrm{ml}$ did not enhance the inhibitory effect (Fig. 2A). As shown by CCK-8 assay, the inhibitory effect on cell proliferation was observed in the cells cultured in $20 \% \mathrm{O}_{2}$ from day $2(\mathrm{P}<0.05)$, and in the cells cultured in $3 \% \mathrm{O}_{2}$ on day $3(\mathrm{P}<0.05)$ (Fig. $\left.2 \mathrm{~B}\right)$. The absolute value of the decrease in proliferation was greater in the cells cultured in low oxygen conditions than in those cultured in normal oxygen conditions.

$M P$ not only inhibits the gene and protein expression of HIF-1 $\alpha$ and its downstream genes, VEGF and PGK1, but also that of Hesl in the Notch signaling pathway in NPCs in vitro. To examine the effects of MP on the HIF- $1 \alpha-\mathrm{VEGF}$ signaling pathway in NPCs, HIF-1 $\alpha$ and its downstream genes, VEGF and PGK1, were investigated in the cells cultured in 

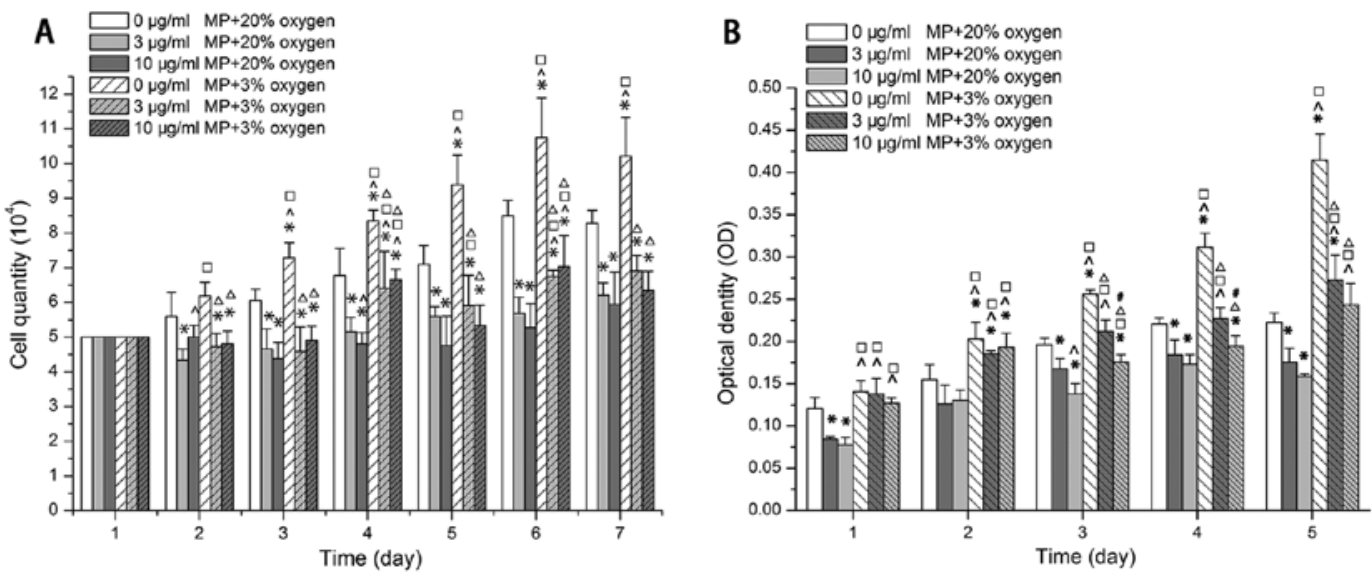

Figure 2. Low oxygen promoted proliferation, but methylprednisolone (MP) inhibited proliferation under both low $\left(3 \% 0_{2}\right)$ and normal (20\% $\left.0_{2}\right)$ oxygen conditions. Increasing the dose of MP (from 3 to $10 \mu \mathrm{g} / \mathrm{ml}$ ) did not enhance the inhibitory effect. (A) Results of cell quantitative analysis (x10 ${ }^{4}$ ). Data are expressed as the means $\pm \mathrm{SD}, \mathrm{n}=3$. (B) Results of CCK-8 assay optical density (OD). Following the addition of MP, the OD value of the cells cultured in in low oxygen $\left(3 \% \mathrm{O}_{2}\right)$ was still higher than that of the cells cultured in normoxic conditions $\left(20 \% \mathrm{O}_{2}\right)$. The OD values formed from the data at 450 minus 630 nm after the cell medium OD value substracted as a blank. Data are expressed as the means $\pm \mathrm{SD}, \mathrm{n}=3$. ${ }^{*} \mathrm{P}<0.05,(0 \mu \mathrm{g} / \mathrm{ml} \mathrm{MP}+20 \%$ oxygen $) \mathrm{vs}$. $(3 \mu \mathrm{g} / \mathrm{ml}$ $\mathrm{MP}+20 \%$ oxygen $),(10 \mu \mathrm{g} / \mathrm{ml} \mathrm{MP}+20 \%$ oxygen $),(0 \mu \mathrm{g} / \mathrm{ml} \mathrm{MP}+3 \%$ oxygen $),(3 \mu \mathrm{g} / \mathrm{ml} \mathrm{MP}+3 \%$ oxygen $),(10 \mu \mathrm{g} / \mathrm{ml} \mathrm{MP}+3 \%$ oxygen $) ;{ }^{\wedge} \mathrm{P}<0.05,(3 \mu \mathrm{g} / \mathrm{ml}$ $\mathrm{MP}+20 \%$ oxygen $)$ vs. $(10 \mu \mathrm{g} / \mathrm{ml} \mathrm{MP}+20 \%$ oxygen $),(0 \mu \mathrm{g} / \mathrm{ml} \mathrm{MP}+3 \%$ oxygen $),(3 \mu \mathrm{g} / \mathrm{ml} \mathrm{MP}+3 \%$ oxygen $),(10 \mu \mathrm{g} / \mathrm{ml} \mathrm{MP}+3 \%$ oxygen $) ;$ ㅁ $<0.05,(10 \mu \mathrm{g} /$ $\mathrm{ml} \mathrm{MP}+20 \%$ oxygen $)$ vs. $(0 \mu \mathrm{g} / \mathrm{ml} \mathrm{MP}+3 \%$ oxygen $),(3 \mu \mathrm{g} / \mathrm{ml} \mathrm{MP}+3 \%$ oxygen $),(10 \mu \mathrm{g} / \mathrm{ml} \mathrm{MP}+3 \%$ oxygen $) ;{ }^{\Delta} \mathrm{P}<0.05,(0 \mu \mathrm{g} / \mathrm{ml} \mathrm{MP}+3 \%$ oxygen $) \mathrm{vs} .(3 \mu \mathrm{g} /$ $\mathrm{ml} \mathrm{MP}+3 \%$ oxygen $),(10 \mu \mathrm{g} / \mathrm{ml} \mathrm{MP}+3 \%$ oxygen $) ;{ }^{\prime \prime} \mathrm{P}<0.05,(3 \mu \mathrm{g} / \mathrm{ml} \mathrm{MP}+30 \%$ oxygen $) \mathrm{vs} .(10 \mu \mathrm{g} / \mathrm{ml} \mathrm{MP}+3 \%$ oxygen $)$.

20 and $3 \% \mathrm{O}_{2}$. Unlike in non-stem cells, the HIF-1 $\alpha$ protein did not undergo proteosomal degradation in the NPCs cultured in $20 \% \mathrm{O}_{2}$ (Fig. 3A). Low oxygen induced the expression of the HIF-1 $\alpha$ gene (Fig. 3C) and protein (Fig. 3A and B) in the cells cultured in $3 \% \mathrm{O}_{2}$ compared to those cultured in $20 \% \mathrm{O}_{2}$ and not treated with MP $(0 \mu \mathrm{g} / \mathrm{ml} \mathrm{MP})$. However, following treatment with $10 \mu \mathrm{g} / \mathrm{ml} \mathrm{MP}, \mathrm{HIF}-1 \alpha$ expression was inhibited in the cells cultured in both 20 and $3 \% \mathrm{O}_{2}$, although the decrease was more significant in the cells cultured in a low oxygen enviroment (Fig. 3B and C). VEGF and PGK1 mRNA expression (in the cells treated with $0 \mu \mathrm{g} / \mathrm{ml} \mathrm{MP}$ ) increased in the cells cultured in $3 \% \mathrm{O}_{2}$ by approximately 2-fold compared to those cultured in $20 \% \mathrm{O}_{2}$; however, following treatment with $\mathrm{MP}(10 \mu \mathrm{g} / \mathrm{ml})$ their expression was suppressed only in the cells cultured in $3 \% \mathrm{O}_{2}$ but not in those cultured in normoxic conditions (Fig. 3D and E). Although VEGF expression in the cells cultured in a low oxygen enviroment was still higher than that in the cells culrured in a normoxic enviroment and treated with $10 \mu \mathrm{g} / \mathrm{ml} \mathrm{MP,} \mathrm{the} \mathrm{abso-}$ lute decrease in its expression was more obvious in the cells cultured in a low oxygen enviroment (Fig. 3D). Hes1 expression also increased by approximately 1.9 -fold in the cells cultured in $3 \% \mathrm{O}_{2}$ and not treated with MP $(0 \mu \mathrm{g} / \mathrm{ml})$. MP also inhibited the expression of Hes1 in the cells cultured in 3 and $20 \% \mathrm{O}_{2}$, which suggests that MP affects the Notch signaling pathway (Fig. 3F).

MP only suppresses the expression of the Notch signaling pathway downstream protein, Hes1, but not that of upstream NICD. As shwon by our results (Fig. 3F), MP can affect the Notch signaling pathway. Low oxygen conditions can also help maintain the undifferentiated state of NPCs by regulating the Notch signal pathway (11). Therefore, we examined the protein levels of the Notch pathway upstream protein, NICD, and the downstream protein, Hes1, in the NPCs following treatment with or without MP under low oxygen and normoxic conditions. The results from western blot analysis revealed that: i) NICD expression was increased (without MP) in the cells cultured in
$3 \% \mathrm{O}_{2}$ compared to those cultured in $20 \% \mathrm{O}_{2}$. MP $(10 \mu \mathrm{g} / \mathrm{ml})$ did not have an inhibitory effect on NICD expression in the cells cultured in 3 and $20 \% \mathrm{O}_{2}$. That is, MP did not affect the Notch signaling pathway by altering NICD expression (Fig. 4A and $\mathrm{B})$. ii) In the cells cultured in 20 and $3 \% \mathrm{O}_{2}$ without DAPT, Hes1 expression increased more significantly in the cells cultured in low oxygen conditions $(\mathrm{P}<0.05)$. MP $(10 \mu \mathrm{g} / \mathrm{ml})$ suppressed the protein expression of Hes1 (Fig. 4A and C) in the Notch signaling pathway and more prominent inhibitory effects were observed in the cells cultured in a low oxygen enviroment $(\mathrm{P}<0.05)$; the expression of Hes1 showed the same tendency as HIF-1 $\alpha$ (Fig. 3A and C). iii) After blocking the expression of NICD with $10 \mu \mathrm{M}$ DAPT (Fig. 4A), Hes1 expression was not elevated under low oxygen conditions, but remained at levels similar to those observed under normoxic conditions ( $\mathrm{P}>0.05)$; however, Hes1 expression still decreased following treatment with MP (10 $\mu \mathrm{g} / \mathrm{ml})$ (Fig. 4C). These results suggest that MP affects the differentiation of NPCs by regulating Hes1 expression without influencing NICD expression.

MP decreases the proportion of nestin-positive NPCs more significantly in a low oxygen enviroment and affects NPC differentiation with a decrease in the number of astrocytes, and a slight increase in the number of neurons. As shown by our results from western blot analysis, MP decreased the expression of Hes1, which indicated that MP can affect NPC differentiation. Thus, we examined the proportion of nestin-, GFAP- and MAP2-positive NPCs following 3 days of culture with 5\% FBS by FACS, as previously described (15). The proportion of nestin-positive NPCs $(0 \mu \mathrm{g} / \mathrm{ml} \mathrm{MP})$ cultured in normoxic conditions (51.8 $\pm 2.46 \%$; Fig. 5A-3) was almost the same as that of the NPCs cultured in a low oxygen enviroment $(49.27 \pm 1.01 \%)(\mathrm{P}>0.05$; Fig. 5A-5). Similar results were observed for the GFAP- and MAP2-positive cells (not treated with MP) $(\mathrm{P}>0.05$; Fig. $5 \mathrm{D}$ and $\mathrm{F})$. Following the addition of MP $(10 \mu \mathrm{g} / \mathrm{ml})$, the number of nestin-positive cells 
A

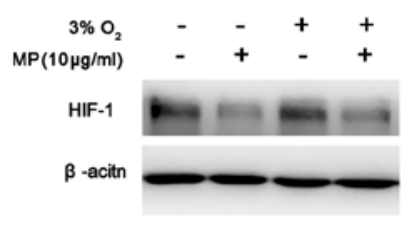

B
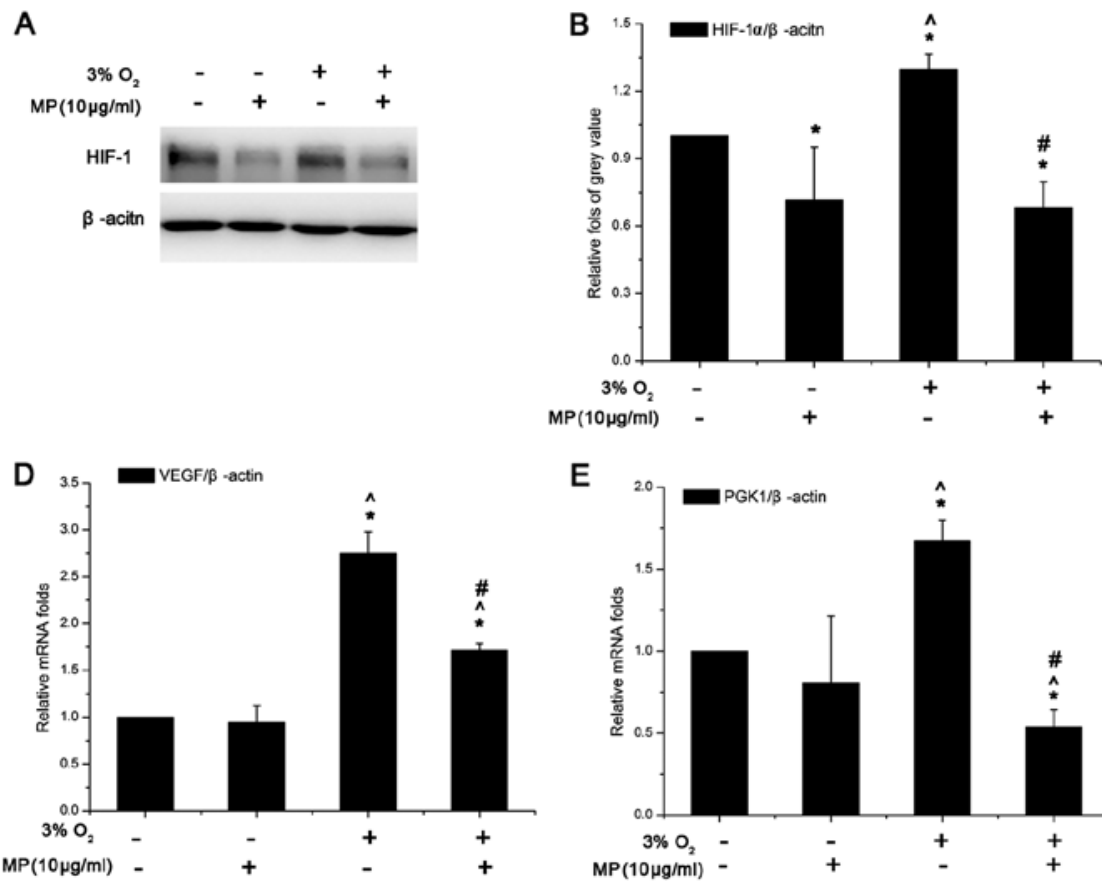

E

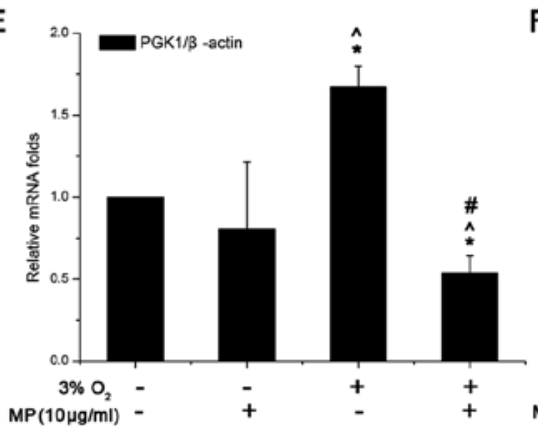

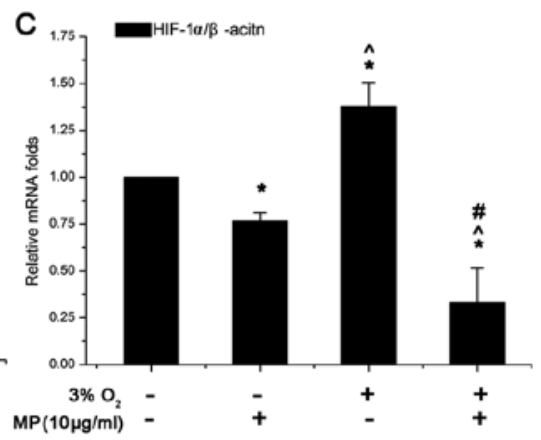

$\mathrm{F}$

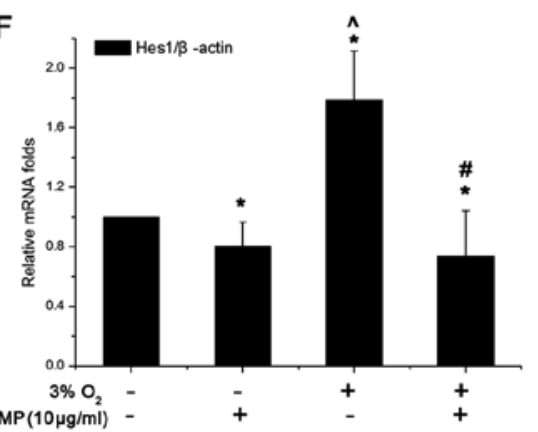

Figure 3. (A) Western blot analysis of hypoxia-inducible factor-1 $\alpha$ (HIF-1 $\alpha)(100 \mathrm{kDa})$. (B) The relative fold of protein HIF-1 $\alpha$ compared to $\beta$-actin was increased in the cells cultured in $3 \% \mathrm{O}_{2}+(0 \mu \mathrm{g} / \mathrm{ml})$ methylprednisolone (MP). Both under normoxic and low oxygen conditions, HIF-1 $\alpha$ protein expression was suppressed. Data are expressed as the means $\pm \mathrm{SD}, \mathrm{n}=3$. (C-F) Results of quantitative PCR. The relative folds of target mRNA compared to housekeeping mRNA $\beta$-actin (ACTIN) were calculated form a $\mathrm{Cp}$ value. Data are expressed as the means $\pm \mathrm{SD}, \mathrm{n}=3$. (C) HIF-1 $\alpha$ increased by approximately 1.5 -fold in low oxygen $\left(3 \% \mathrm{O}_{2}\right)$ compared to normoxic conditions $\left(20 \% \mathrm{O}_{2}\right.$ ), and its gene expression was suppressed (approximately 0.75 -fold in normoxic and approximately 0.4 -fold in low oxygen conditions) following treatment with MP $(10 \mu \mathrm{g} / \mathrm{ml})$. The suppressive effects were more prominent in a low oxygen than in the normoxic environment ( ${ }^{\mathrm{P}}<0.05$ between the group of $20 \% \mathrm{O}_{2}+0 \mu \mathrm{g} / \mathrm{ml} \mathrm{MP}$ and $3 \% \mathrm{O}_{2}+0 \mu \mathrm{g} / \mathrm{ml} \mathrm{MP}$ ). (D) VEGF expression increased by approximately 2.3 -fold in low oxygen ( $3 \% \mathrm{O}_{2}$ ), when added MP $(10 \mu \mathrm{g} / \mathrm{ml})$ the inhibition effect only worked in low oxygen. In low oxygen the VEGF still expressed higher than in in the normoxic conditions even following treatment with MP. (E) PGK1 expression also increased by approximately 1.7-fold in low oxygen when no MP was added. MP was more effective in decreasing PGK1 expression compared to VEGF. (F) Hes1 expression also increased by approximately 1.9 -fold in the cells cultured in $3 \% \mathrm{O}_{2}+(0 \mu \mathrm{g} / \mathrm{ml})$ MP. MP also inhibited the expression of Hes1 under both oxygen conditions, which suggests that MP affects the Notch signaling pathway. ${ }^{*}<<0.05,\left(20 \% \mathrm{O}_{2}\right)$ normoxia $+(0 \mu \mathrm{g} / \mathrm{ml})$ MP group vs. $\left(20 \% \mathrm{O}_{2}\right)$ normoxia $+(10 \mu \mathrm{g} / \mathrm{ml})$ MP group, $\left(3 \% \mathrm{O}_{2}\right)$ low oxygen $+(0 \mu \mathrm{g} / \mathrm{ml}) \mathrm{MP}$ group and $\left(3 \% \mathrm{O}_{2}\right)$ low oxygen $+(10 \mu \mathrm{g} / \mathrm{ml})$ MP group; ${ }^{\wedge} \mathrm{P}<0.05,\left(20 \% \mathrm{O}_{2}\right)$ normoxia $+(10 \mu \mathrm{g} / \mathrm{ml})$ MP group vs. $\left(3 \% \mathrm{O}_{2}\right)$ low oxygen $+(0 \mu \mathrm{g} / \mathrm{ml})$ MP group and $\left(3 \% \mathrm{O}_{2}\right)$ low oxygen $+(10 \mu \mathrm{g} / \mathrm{ml}) \mathrm{MP}$ group; ${ }^{"} \mathrm{P}<0.05,\left(3 \% \mathrm{O}_{2}\right)$ low oxygen $+(0 \mu \mathrm{g} / \mathrm{ml})$ MP group vs. $\left(3 \% \mathrm{O}_{2}\right)$ low oxygen $+(10 \mu \mathrm{g} / \mathrm{ml}) \mathrm{MP}$ group.

A

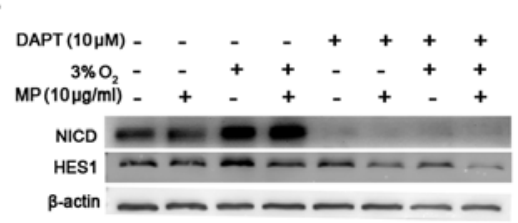

B

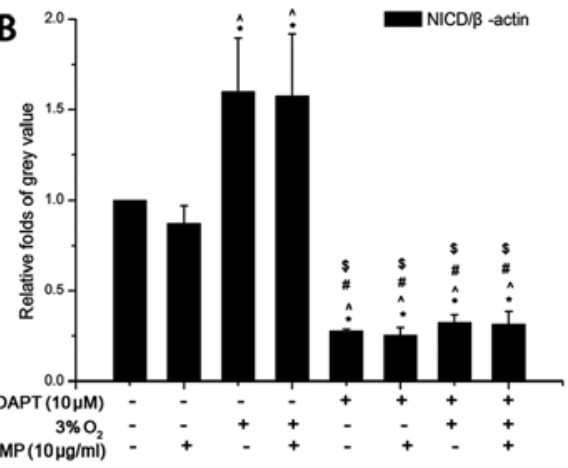

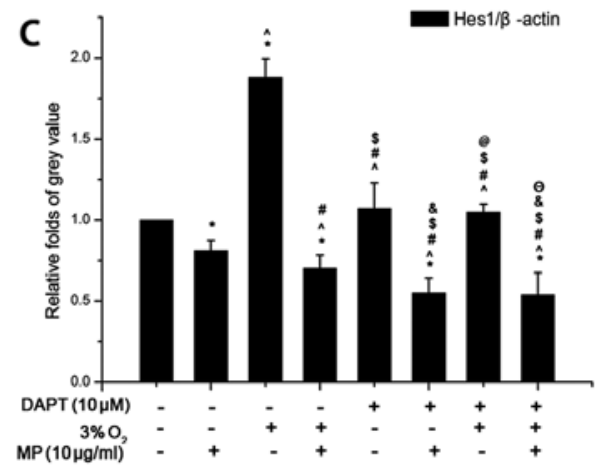

Figure 4. Western blot analysis was carried out with the cell lysis buffer of neural progenitor cells (NPCs) following treatment. In response to methylprednisolone (MP) treatment, low oxygen decreased the expression of the Notch signaling pathway, downstream protein, Hes1, but not that of upstream Notch-1 intracelluar domain (NICD). After blocking NICD with an inhibitor (DAPT) MP still inhibited the expression of Hes1. Three independent experiments were performed. The data of target protein compared to internal reference protein are expressed as the means $\pm \mathrm{SD}, \mathrm{n}=3$. Low oxygen $\left(3 \% \mathrm{O}_{2}\right)$, normoxia $\left(20 \% \mathrm{O}_{2}\right)$ and $\mathrm{MP}$ was added at a concentration of $10 \mu \mathrm{g} / \mathrm{ml}$, the NICD inhibitor, DAPT, was used at a concentration of $10 \mu \mathrm{M}$. (A) $\beta$-actin was an internal reference protein (approximately $45 \mathrm{kDa}$ ), Hes1 (approximately $30 \mathrm{kDa}$ ), NICD (approximately $110 \mathrm{kDa}$ ). (B) The expression of NICD was elevated under low oxygen conditions compared to normoxic conditions following treatment of the cells with $0 \mu \mathrm{g} / \mathrm{ml} \mathrm{MP}\left({ }^{*} \mathrm{P}<0.05\right)$. MP did not have an inhibitory effect on NICD following treatment of the cells with $10 \mu \mathrm{g} / \mathrm{ml}$ MP under both normoxic and low oxygen conditions. After the addition of DAPT (10 $\mu \mathrm{M})$, NICD expression was significantly inhibited and MP did not affect the expression of NICD. (C) The relative fold of Hes1 compared to $\beta$-actin was increased in the cells cultured in low oxygen without MP ( $\mathrm{P}<0.05)$, but MP was more effective in a low oxygen environment when applied to the NPCs ( $\left.{ }^{\wedge} \mathrm{P}<0.05\right)$. Following treatment with DAPT $(10 \mu \mathrm{M}) \mathrm{Hes} 1$ expression did not increase in low oxygen compared to normoxia $\left({ }^{\&} \mathrm{P}>0.05\right)$, but Hes1 expression was still inhibited by $\mathrm{MP}(10 \mu \mathrm{g} / \mathrm{ml})\left({ }^{\&} \mathrm{P}<0.05 ;{ }^{\ominus} \mathrm{P}<0.05\right) .{ }^{*} \mathrm{P}<0.05,\left(20 \% \mathrm{O}{ }_{2}\right)$ normoxia $+(0 \mu \mathrm{g} /$ $\mathrm{ml}) \mathrm{MP}$ group $+0 \mu \mathrm{M}$ DAPT vs. the other 6 groups apart from the control group; ${ }^{\wedge} \mathrm{P}<0.05,\left(20 \% \mathrm{O}_{2}\right)$ normoxia $+(10 \mu \mathrm{g} / \mathrm{ml}) \mathrm{MP}$ group $+0 \mu \mathrm{M} \mathrm{DAPT}$ vs. the other 6 groups apart from the control group; ${ }^{\#} \mathrm{P}<0.05,\left(3 \% \mathrm{O}_{2}\right)$ low oxygen $+(0 \mu \mathrm{g} / \mathrm{ml}) \mathrm{MP}$ group $+0 \mu \mathrm{M}$ DAPT vs. the other 6 groups apart from the control group; ${ }^{\$} \mathrm{P}<0.05$ vs. $\left(3 \% \mathrm{O}_{2}\right)$ low oxygen $+(10 \mu \mathrm{g} / \mathrm{ml}) \mathrm{MP}$ group $+0 \mu \mathrm{M}$ DAPT vs. the other 6 groups apart from the control group; ${ }^{\circ} \mathrm{P}<0.05,\left(20 \% \mathrm{O}{ }_{2}\right)$ normoxia $+(0 \mu \mathrm{g} / \mathrm{ml})$ $\mathrm{MP}$ group $+10 \mu \mathrm{M}$ DAPT vs. the other 6 groups apart from the control group; ${ }^{\circledR} \mathrm{P}<0.05,\left(20 \% \mathrm{O}_{2}\right)$ normoxia $+(10 \mu \mathrm{g} / \mathrm{ml}) \mathrm{MP}$ group $+10 \mu \mathrm{M} \mathrm{DAPT}$ vs. the other 6 groups apart from the control group; ${ }^{\Theta} \mathrm{P}<0.05,\left(3 \% \mathrm{O}_{2}\right)$ low oxygen $+(0 \mu \mathrm{g} / \mathrm{ml}) \mathrm{MP}$ group $+10 \mu \mathrm{M}$ DAPT vs. the other 6 groups apart from the control group. 

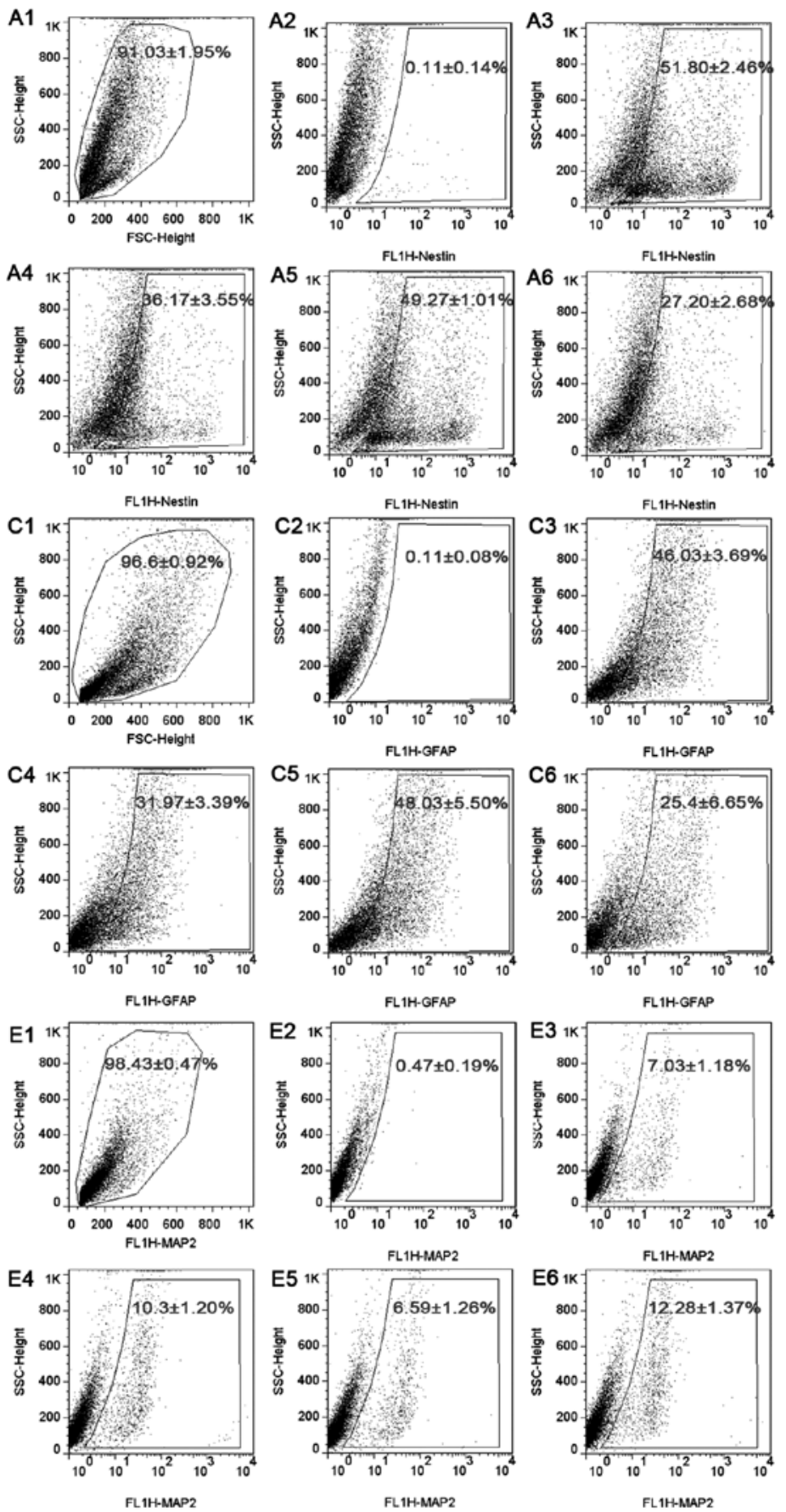
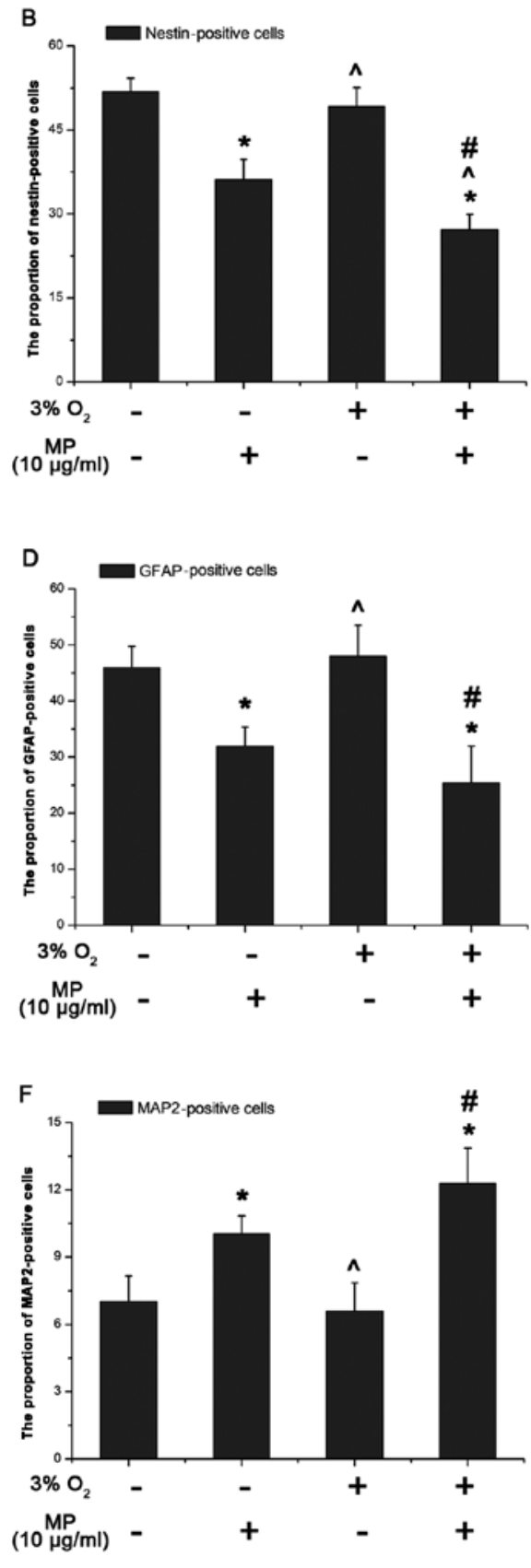

Figure 5. Fluorescence-activated cell sorting (FACS) of neural progenitor cells (NPCs) cultured 3 days after the experimental conditions. All data are expressed as the means $\pm \mathrm{SD}, \mathrm{n}=3$. (A and B) The cell gated for analysis were approximately $91.03 \pm 1.95 \%$ (A-1). The cells incubated only with secondary antibody (FITC) were detected as a positive control. Each sample had a positive control and the positive gate was set according to the control. Only $0.11 \pm 0.14 \%$ (A-2) cells were false positive cells. With $0 \mu \mathrm{g} / \mathrm{ml}$ methylprednisolone (MP), the percentage of nestin-positive NPCs under normoxic conditions (51.8 $\pm 2.46 \%$ ) (A-3) was almost the same as that in low oxygen (49.27 $\pm 1.01 \%$ ) (A-5). After the addition of $10 \mu \mathrm{g} / \mathrm{ml} \mathrm{MP}$, the nestin-positive cell mean frequencies decreased in both oxygen concentrations $(36.17 \pm 3.55 \%)$ (A-4), more prominently in low oxygen (27.20 $\pm 2.68 \%)(\mathrm{A}-6)$. (C and D) GFAP-positive cells represent the astrocytes differentiated from NPCs. Approximately $96.60 \pm 0.92 \%$ cells $(\mathrm{C}-1)$ were gated. The positive control was as mentioned above. Approximately $0.11 \pm 0.08 \%$ cells $(\mathrm{C}-2)$ were false positive. The percentage of GFAP-positive NPCs $(46.03 \pm 3.69 \%)$ was almost the same as that in low oxygen $(48.03 \pm 5.50 \%)$ with $0 \mu \mathrm{g} / \mathrm{ml} \mathrm{MP}$. MP $(10 \mu \mathrm{g} /$ $\mathrm{ml}$ ) inhibited the dirrentiation of NPCs into astrocytes [(C-6) $27.20 \pm 2.68 \%$ in low oxygen; (C-4) $36.17 \pm 3.55 \%$ in normoxia]. (E and F) MAP2-positive cells represent the neurons differentiated from NPCs. More NPCs differentiated into neurons when treated with $\mathrm{MP}(10 \mu \mathrm{g} / \mathrm{ml}) \mathrm{both}$ under normoxic $(10.30 \pm 1.20 \%)$ (E-4) and low oxygen conditions $(12.28 \pm 1.37 \%)(\mathrm{E}-6){ }^{*} \mathrm{P}<0.05,\left(20 \% \mathrm{O}_{2}\right)$ normoxia $+(0 \mu \mathrm{g} / \mathrm{ml}) \mathrm{MP}$ group vs. $(20 \% \mathrm{O}$ ) normoxia $+(10 \mu \mathrm{g} / \mathrm{ml}) \mathrm{MP}$ group, $\left(3 \% \mathrm{O}_{2}\right)$ low oxygen $+(0 \mu \mathrm{g} / \mathrm{ml}) \mathrm{MP}$ group and $\left(3 \% \mathrm{O}_{2}\right)$ low oxygen $+(10 \mu \mathrm{g} / \mathrm{ml}) \mathrm{MP}$ group; ${ }^{\wedge} \mathrm{P}<0.05,\left(20 \% \mathrm{O}_{2}\right)$ normoxia $+(10 \mu \mathrm{g} / \mathrm{ml}) \mathrm{MP}$ group vs. $\left(3 \% \mathrm{O}_{2}\right)$ low oxygen $+(0 \mu \mathrm{g} / \mathrm{ml}) \mathrm{MP}$ group and $\left(3 \% \mathrm{O}_{2}\right)$ low oxygen $+(10 \mu \mathrm{g} / \mathrm{ml}) \mathrm{MP}$ group; ${ }^{\#} \mathrm{P}<0.05$, $\left(3 \% \mathrm{O}_{2}\right)$ low oxygen $+(0 \mu \mathrm{g} / \mathrm{ml}) \mathrm{MP}$ group vs. $\left.(3 \% \mathrm{O})\right)$ low oxygen $+(10 \mu \mathrm{g} / \mathrm{ml})$ MP group.

decreased more prominently under low oxygen conditions $\left(3 \% \mathrm{O}_{2}\right)(27.20 \pm 2.68 \%$; Fig. $5 \mathrm{~A}-6)$ than under normal oxygen conditions $\left(20 \% \mathrm{O}_{2}\right)(36.17 \pm 3.55 \%$; Fig. $5 \mathrm{~A}-4)$.
These results suggested that MP induced the differentiation of the NPCs into non-stem like cells. Following treatment with MP $(10 \mu \mathrm{g} / \mathrm{ml})$ the number of GFAP-positive cells 
decreased under both normoxic $(31.97 \pm 3.39 \%)$ (Fig. 5C-4) and hypoxic conditions $(25.40 \pm 6.65 \%$; Fig. 5C-6) with a similar tendency as the nestin-positive cells (Fig. 5B). This suggested that MP suppressed the differentiation of NPCs into astrocytes (Fig. 5D). On the contrary, more NPCs differentiated into neurons, as the proportion of MAP2-positive cells was elevated following treatment with MP $(10 \mu \mathrm{g} / \mathrm{ml})$ both under normoxic $(10.30 \pm 1.20 \%$; Fig. $5 \mathrm{E}-4)$ and hypoxic conditions (12.28 $\pm 1.37 \%$; Fig. 5E-6).

\section{Discussion}

In this study, we explored the effects of MP on NPC proliferation and differentiation under both low oxygen and normoxic conditions in vitro. Our results revealed that a low oxygen enviroment promoted the proliferation of NPCs; however, MP inhibited NPC proliferation, reduced the percentage of stem-like cells and affected cell differentiation under both normoxic and hypoxic conditions. MP suppressed the expression of HIF- $1 \alpha$ and its downstream target genes, VEGF and PGK1, in a low oxygen enviroment. Furthermore, the Notch signaling pathway downstream proteins, Hes1, which play an important role in the regulation of NPC differentiation, were downregulated following treatment with MP.

Our previous study and the study by Schröter et al showed that MP exerted inhibitory effects on the proliferation of endogenous NPCs in vitro and in vivo following SCI $(7,8)$; however, the mechanisms involved remain unclear. A number of studies have demonstrated that a low oxygen enviroment promotes the proliferation of neural stem cells in vitro and in vivo (5-7). In a previous study, Zhao et al indicated that HIF-1 $\alpha$ is critical in this process, as when HIF-1 $\alpha$ expression was knocked down, the proliferation of embryonic mesencephalon-derived neural stem cell was suppressed (16). It has also been demonstrated that dexamethasone attenuates HIF-1 activity in a GR-dependent manner and suppresses VEGF expression in HepG2 cells (17). However, to the best of our knowledge, no study to date has focused on the effects of MP on spinal cordderived NPCs in a low oxygen enviroment. In this study, we first demonstrated that in a low oxygen enviroment, MP had an inhibitory effect on the proliferation of rat spinal cord-derived NPCs and decreased the expression of HIF-1 $\alpha$ in the NPCs at the mRNA and protein level.

In their study, Murata et al indicated that Hes1 directly promotes the proliferation of embryonic carcinoma cells (18). Blocking Hes1 expression has been shown to suppress human neural stem cell proliferation in vitro by stimulating the of expression of Cyclin-dependent Cdk kinase inhibitor (19). In addition, the activation of the Notch receptor promotes the survival of fetal neural stem cells by inducing the expression of Hes3 (20). Dexamethasone has been shown to reduce the expression of Hes1 in cochlear cells following exposure to noise (21). In this study, we demonstrated that MP reduced the expression of Hes1 under both normoxic and hypoxic conditions and inhibited the proliferation of spinal cord-derived NPCs.

The Notch signaling pathway plays a very important role in regulating the differentiation of NPCs $(10,22)$. In mouse neural stem cells, the activation of Notch signaling promotes the differentiation of astrocytes, but inhibits the differentiation of oligodendrocytes and neurons (23). It has also been demonstrated that Notch can prevent the degradation of nestin protein in MHP36 neural stem cells (24). Blocking Hes1 in human neural stem cells in vitro stimulates the differentiation of GABAergic neurons (19). Recent evidence also indicates novel roles for HIF-1 $\alpha$ in stem cell differentiation through the modulation of Notch signaling pathways (25). A previous study demonstrated that HIF-1 $\alpha$ was vital to maintain the activation of the Notch-1 pathway and maintain MDB stem cell viability and proliferation (26). Low oxgen levels in embryonic NPCs enhances Notch signaling through direct HIF-1 $\alpha$ binding to activated Notch-1 (NICD), resulting in the increased stabilization of NICD and the transcription of Notch-1 target genes (11). Our results demonstrated that Hes1 expression levels were almost the same as those of HIF-1 $\alpha$ in the cells cultured in 20 and $3 \% \mathrm{O}_{2}$ without DAPT treatment. Previous studies have shown that dexamethasone inhibits HIF-1 $\alpha$ protein expression in Th and HepG2 cells $(9,17)$. These data suggest that glucocorticoids suppress the expression of Notch through the inhibition of HIF-1 $\alpha$. Dexamethasone can also decrease the expression of Hes1 (21), which suggests taht glucocorticoids can also directly restrain the Notch signaling pathway. Our study demonstrated MP did not affect NICD, but inhibited HIF-1 $\alpha$ and the Notch signaling pathway downstream protein, Hes1, in spinal cord-derived cells. The effects was more notable in a low oxygen enviroment. After blocking the expression of NICD with DAPT, MP still inhibited the expression of Hes1. Those results demonstrate a possible mechanism through MP affects NPCs in a low oxygen enviroment. Our results from FACS analysis suggested that MP affected the differentiation of spinal cordderived NPCs by suppressing HIF-1 $\alpha$ and Hes1, which led to a decrease in the proportion of progenitor cells and the percentage of astrocytes, and a slight increase in the number of neurons.

In conclusion, our results confirm that MP significantly inhibits the proliferation of NPC and affects their differentiation, altering the proportion astrocytes in a low oxygen enviroment in vitro. Our results from PCR and western blot analysis provide insight into the molecular mechanisms responsible for the inhibition of proliferation and the effects on differentiation mediated by MP and suggestthat the downregulation of HIF-1 $\alpha$ and Hes1 play a vital role in this process.

\section{Acknowledgements}

This study was supported by grants from the Health Public Scientific Research Fund of China (201002018) and the Program of National Natural Science Foundation of China (81000529) and the Guangdong Science and Technology Program (2011B031800019) and the National Natural Foundation of China-Guangdong Province Combined Foundation (U1301223).

\section{References}

1. Hausmann ON: Post-traumatic inflammation following spinal cord injury. Spinal Cord 41: 369-378, 2003.

2. Jones TB,McDanielEE and Popovich PG:Inflammatory-mediated injury and repair in the traumatically injured spinal cord. Curr Pharm Des 11: 1223-1236, 2005.

3. Majmundar AJ, Wong WJ and Simon MC: Hypoxia-inducible factors and the response to hypoxic stress. Mol Cell 40: 294-309, 2010.

4. Horie N, So K, Moriya T, et al: Effects of oxygen concentration on the proliferation and differentiation of mouse neural stem cells in vitro. Cell Mol Neurobiol 28: 833-845, 2008. 
5. Zhu LL, Wu LY, Yew DT and Fan M: Effects of hypoxia on the proliferation and differentiation of NSCs. Mol Neurobiol 31 231-242, 2005.

6. Chen X, Tian Y, Yao L, Zhang J and Liu Y: Hypoxia stimulates proliferation of rat neural stem cells with influence on the expression of cyclin D1 and c-Jun N-terminal protein kinase signaling pathway in vitro. Neuroscience 165: 705-714, 2010.

7. Schröter A, Lustenberger RM, Obermair FJ and Thallmair M: High-dose corticosteroids after spinal cord injury reduce neural progenitor cell proliferation. Neuroscience 161: 753-763, 2009

8. Li SY, Wang P, Tang Y, Huang L, Wu YF and Shen HY: Analysis of methylprednisolone-induced inhibition on the proliferation of neural progenitor cells in vitro by gene expression profiling. Neurosci Lett 526: 154-159, 2012.

9. Gaber T, Schellmann S, Erekul KB, et al: Macrophage migration inhibitory factor counterregulates dexamethasone-mediated suppression of hypoxia-inducible factor- 1 alpha function and differentially influences human $\mathrm{CD} 4^{+} \mathrm{T}$ cell proliferation under hypoxia. J Immunol 186: 764-774, 2011.

10. Alexson TO, Hitoshi S, Coles BL, Bernstein A and van der Kooy D: Notch signaling is required to maintain all neural stem cell populations-irrespective of spatial or temporal niche. Dev Neurosci 28: 34-48, 2006.

11. Gustafsson MV, Zheng X, Pereira T, et al: Hypoxia requires notch signaling to maintain the undifferentiated cell state. Dev Cell 9: 617-628, 2005.

12. Oya S, Yoshikawa G, Takai K, et al: Attenuation of Notch signaling promotes the differentiation of neural progenitors into neurons in the hippocampal CA1 region after ischemic injury. Neuroscience 158: 683-692, 2009.

13. Shihabuddin LS, Ray J and Gage FH: FGF-2 is sufficient to isolate progenitors found in the adult mammalian spinal cord Exp Neurol 148: 577-586, 1997.

14. Shihabuddin LS, Horner PJ, Ray J and Gage FH: Adult spinal cord stem cells generate neurons after transplantation in the adult dentate gyrus. J Neurosci 20: 8727-8735, 2000.

15. Sergent-Tanguy S, Chagneau C, Neveu I and Naveilhan P: Fluorescent activated cell sorting (FACS): a rapid and reliable method to estimate the number of neurons in a mixed population. J Neurosci Methods 129: 73-79, 2003
16. Zhao T, Zhang CP, Liu ZH, et al: Hypoxia-driven proliferation of embryonic neural stem/progenitor cells-role of hypoxia-inducible transcription factor-1alpha. FEBS J 275: 1824-1834, 2008.

17. Wagner AE, Huck G, Stiehl DP, Jelkmann W and Hellwig-Burgel T: Dexamethasone impairs hypoxia-inducible factor-1 function. Biochem Biophys Res Commun 372: 336-340, 2008.

18. Murata K, Hattori M, Hirai N, et al: Hes1 directly controls cell proliferation through the transcriptional repression of p27Kip1. Mol Cell Biol 25: 4262-4271, 2005.

19. Kabos P, Kabosova A and Neuman T: Blocking HES1 expression initiates GABAergic differentiation and induces the expression of p21(CIP1/WAF1) in human neural stem cells. J Biol Chem 277: 8763-8766, 2002.

20. Androutsellis-Theotokis A, Leker RR, Soldner F, et al: Notch signalling regulates stem cell numbers in vitro and in vivo. Nature 442: 823-826, 2006.

21. Wang B, Liu Y, Chi F, Zhang Y, Yang M and Zhu X: Dexamethasone suppresses cochlear Hes1 expression after noise exposure. Acta Otolaryngol 133: 233-238, 2013.

22. Mizutani K, Yoon K, Dang L, Tokunaga A and Gaiano N: Differential Notch signalling distinguishes neural stem cells from intermediate progenitors. Nature 449: 351-355, 2007.

23. Grandbarbe L, Bouissac J, Rand M, Hrabé de Angelis M, Artavanis-Tsakonas S and Mohier E: Delta-Notch signaling controls the generation of neurons/glia from neural stem cells in a stepwise process. Development 130: 1391-1402, 2003.

24. Mellodew K, Suhr R, Uwanogho DA, et al: Nestin expression is lost in a neural stem cell line through a mechanism involving the proteasome and Notch signalling. Brain Res 151: 13-23, 2004.

25. Cunningham LA, Candelario K and Li L: Roles for HIF-1alpha in neural stem cell function and the regenerative response to stroke. Behav Brain Res 227: 410-417, 2012.

26. Pistollato F, Rampazzo E, Persano L, et al: Interaction of HIF1a and Notch signaling regulates medulloblastoma precursor proliferation and fate. Stem Cells 28: 1918-1929, 2010. 